\title{
Daya Dukung Ketersediaan Air dan Pangan di Kecamatan Sukamaju
}

\author{
Ade Mulawarman ${ }^{1}$, *Nurhikmah Paddiyatu², Sumarni B ${ }^{3}$, Rabi’atul Adawia Haupea ${ }^{4}$ \\ ${ }^{1}$ Prodi Kehutanan, Fakultas Pertanian dan Kehutanan, Universitas Sulawesi Barat, Indonesia \\ ${ }^{2}$ Prodi Arsitektur, Fakultas Teknik, Universitas Muhammadiyah Makassar, Indonesia \\ ${ }^{3}$ Prodi Agribisnis, Fakultas Pertanian, Universitas Muhammadiyah Makassar, Indonesia \\ ${ }^{4}$ Dinas Pekerjaan Umum dan Penataan Ruang Provinsi Maluku, Indonesia \\ Alamat Email: nurhikmah@unismuh.ac.id
}

*Alamat korespondensi, Masuk: 12 Jul. 2019, Direvisi: 27 Agt. 2019, Diterima: 5 Sept. 2019

\begin{abstract}
ABSTRAK: Daya dukung merupakan kemampuan lingkungan dalam mendukung kegiatan atau aktivitas penduduk yang hidup di atasnya yang menggunakan ruang untuk kelangsungan hidup. Degradasi lingkungan yang terjadi akibat dampak dari maraknya pembangunan, menimbulkan berbagai upaya peningkatan dalam pemenuhan terhadap ketersediaan air dan pangan sebagai sumber kehidupan. Konversi lahan pertanian menjadi lahan budidaya yang lain atau permukiman menjadikan lahan pertanian tersebut semakin minim pula sebagai penyokong dalam siklus keseimbangan lingkungan. Berbagai riset yang telah dibuktikan bahwa laju pertambahan penduduk atau populasi manusia tidak diiringi dengan pemasokan bahan makanan serta produksi pangan. Oleh karena itu, dalam keberlanjutannya perlu adanya perlindungan serta pengendalian dalam pemanfaatan ruang. Terkait hal tersebut, tujuan dari penelitian ini adalah mengetahui daya dukung lingkungan dalam aspek ketersediaan air dan pangan berbasis indeks jasa ekosistem di kecamatan Sukamaju, Kabupaten Luwu Utara. Metode analisis yang digunakan yaitu perhitungan dan penentuan daya dukung lingkungan indikatif berbasis jasa ekosistem terdiri dari klasifikasi karakterisitik ekoregion (bentang lahan dan tipe vegetasi alami), serta penutupan lahan, perhitungan dan pembuatan peta layanan/kinerja jasa ekosistem dengan metode penjumlahan berbobot (Simple Additive Weighting). Hasil dari penelitian menunjukkan bahwa jasa ekosistem penyediaan air pada kelas rendah sebesar 92,31\% dan kelas tinggi sebesar 0,57\% sedangkan untuk jasa ekosistem penyediaan pangan pada kelas rendah sebesar 24,71\% dan kelas tinggi sebesar $40.68 \%$.
\end{abstract}

Kata kunci: Daya Dukung, Keseimbangan Lingkungan, Air dan Pangan, Jasa Ekosistem

\begin{abstract}
Carrying capacity is the ability of the environment to support the activities or people's activities that living on it who use space for survival. Environmental degradation that occurs due to the impact of rampant constructions, lead to various efforts to increase in the fulfillment of the availability of water and food as a source of life. The conversion of agricultural land into other cultivation lands or settlements makes the agricultural land increasingly minimal as a support in the environmental balance cycle. Various studies have proven that the rate of population growth or the human population is not accompanied by the supply of food and food production. Therefore, in its sustainability there needs to be protection and control in the use of space. Related to this, the purpose of this study is to determine the carrying capacity of the environment in the aspect of water and food availability based on the ecosystem services index in the Sukamaju sub-district, North Luwu Regency. The analytical method used is the calculation and determination of the carrying capacity of indicative environmental services based on ecosystem services consisting of the classification of ecoregional characteristics (landscape and natural vegetation type), as well as land cover, calculation, and map of services/performance of ecosystem services with the weighting method (Simple Additive Weighting). The results of the study showed that ecosystem services for water supply in the low class were $92.31 \%$ and in the high class were $0.57 \%$ while for ecosystem services the provision of food in the low class was $24.71 \%$ and the high class was $40.68 \%$.
\end{abstract}

Keywords: Carrying Capacity, Environmental Balance, Water and Food, Ecosystem Services 


\section{PENDAHULUAN}

Upaya dalam mendukung keberlanjutan suatu wilayah untuk kebutuhan manusia serta makhluk hidup lainnya memerlukan tolak ukur dalam pencapaiannya. Penentuan daya dukung dan daya tampung lingkungan merupakan solusi yang dapat mendukung upaya tersebut.

Daya dukung dan daya tampung lingkungan hidup merupakan hal yang bersifat dinamis dan kompleks, mengingat setiap wilayah memiliki karakteristik geografi, kemampuan sumber daya alam dan jumlah penduduk yang berbeda-beda. Konsep daya dukung secara umum dapat dilihat dari dua sisi yaitu; a) dari sisi ketersediaan, dengan melihat karakteristik wilayah, potensi sumber daya alam yang ada di suatu wilayah, b) dari sisi kebutuhan, yaitu dengan melihat kebutuhan manusia dan makhluk hidup lainnya dan arahan kebijakan prioritas suatu wilayah [1].

Berdasarkan data RDTR kawasan perkotaan Sukamaju Kabupaten Luwu Utara tahun 2018, populasi penduduk kecamatan Sukamaju semakin meningkat dengan laju pertumbuhan penduduk yaitu sebesar $0,48 \%$. Hal tersebut akan memicu pula adanya aktivitas-aktivitas baru seperti kebutuhan akan permukiman dan perumahan, industri, komersial serta kegiatan pembangunan lainnya. Perumahan yang merupakan kebutuhan dasar manusia menjadikan salah satu sarana yang dalam pemanfaatannya sangat berpengaruh pada pola penggunaan air yang ada.

Disamping itu, menurunnya kualitas lingkungan permukiman secara fungsional kualitas pelayanan kondisi fisik bangunan dan lingkungan hunian masyarakat dikarenakan rendahnya tingkat pemenuhan kebutuhan perumahan yang layak [2]. Rumah yang layak untuk tempat tinggal adalah rumah yang harus memenuhi syarat kesehatan sehingga penghuninya tetap sehat. Rumah yang sehat tidak lepas dari ketersediaan prasarana dan sarana terkait seperti penyediaan air bersih, sanitasi pembuangan sampah, tranportasi, dan tersedianya pelayanan sosial [3]. Hal tersebut sesuai dengan pernyataan Beer, dalam Ndoen [4] dalam konteks desain perkotaan yang berkelanjutan ada empat hal mendasar yang perlu dikonservasi untuk menjaga daya dukung lingkungan yakni: kemampuan lahan untuk menjaga ketersediaan makanan, kemampuan lahan untuk menjaga ketersediaan air minum, kemampuan lahan untuk menjaga ketersediaan udara yang bersih dan kemampuan lahan untuk menjaga ketersediaan permukiman yang layak.
Sehingga fokus dalam penelitian ini hanya berada hanya pada lingkup ketersediaan air dan pangan.

Kecamatan Sukamaju termasuk salah satu kawasan budidaya pengembangan alternatif komoditi perkebunan unggulan [5]. Namun beberapa wilayah kecamatan di daerah ini tergolong rawan pangan. Hal tersebut terlihat dari menurunnya luas lahan tanaman kakao serta maraknya organisme pengganggu pada tanaman perkebunan.

Ketidakseimbangan daya dukung yang terjadi pada akhirnya akan menimbulkan dampak negatif bahkan pula dapat mengakibatkan terjadinya bencana lingkungan jika daya dukung lingkungan terhadap ketersediaan air dan pangan telah terlampaui. Penentuan kuterlampauinya ketersediaan oleh kebutuhan air dan pangan dapat dinyatakan melalui status daya dukung lingkungan [6]. Status daya dukung dalam pengendalian serta pemanfaatan ruang demi ketahanan air dan pangan dimasa yang akan datang serta generasi selanjutnya menjadi hal yang sangat penting. Oleh karena itu perlu adanya pembuktian analisis mengenai ketersediaan air dan pangan khususnya di kecamatan Sukamaju guna mewujudkan pembangunan wilayah yang sinergis dengan kelestarian fungsi daya dukungnya.

\section{METODE PENELITIAN}

Lokasi penelitian berada di bagian perkotaan Kecamatan Sukamaju, Kabupaten Luwu Utara Provinsi Sulawesi Selatan (Gambar 1). Sebagai salah satu pusat kegiatan yang berada di Kabupaten Luwu Utara, Kecamatan Sukamaju diarahkan sebagai kawasan agropolitan dalam dokumen perencanaan tata ruang. Sehingga seiring berjalannya waktu, pertumbuhan perkotaan yang diharapkan menjadi kawasan agropolitan akan mengalami degradasi jika tanpa melihat aspek daya dukung lingkungan. Penelitian ini difokuskan pada bagian perkotaan dalam Kecamatan Sukamaju karena bagian perkotaan merupakan area yang sangat agresif perubahan penggunaan lahan. maka dari itu informasi terkait daya dukung lingkungan untuk jasa penyediaan air dan pangan sangat penting untuk mendukung kawasan agropolitan yang berkelanjutan.

Penelitian ini dilakukan dengan perhitungan dan analisis daya dukung lingkungan hidup berdasarkan pendekatan jasa ekosistem. Dalam pendekatan jasa ekosistem terbagi menjadi tiga 


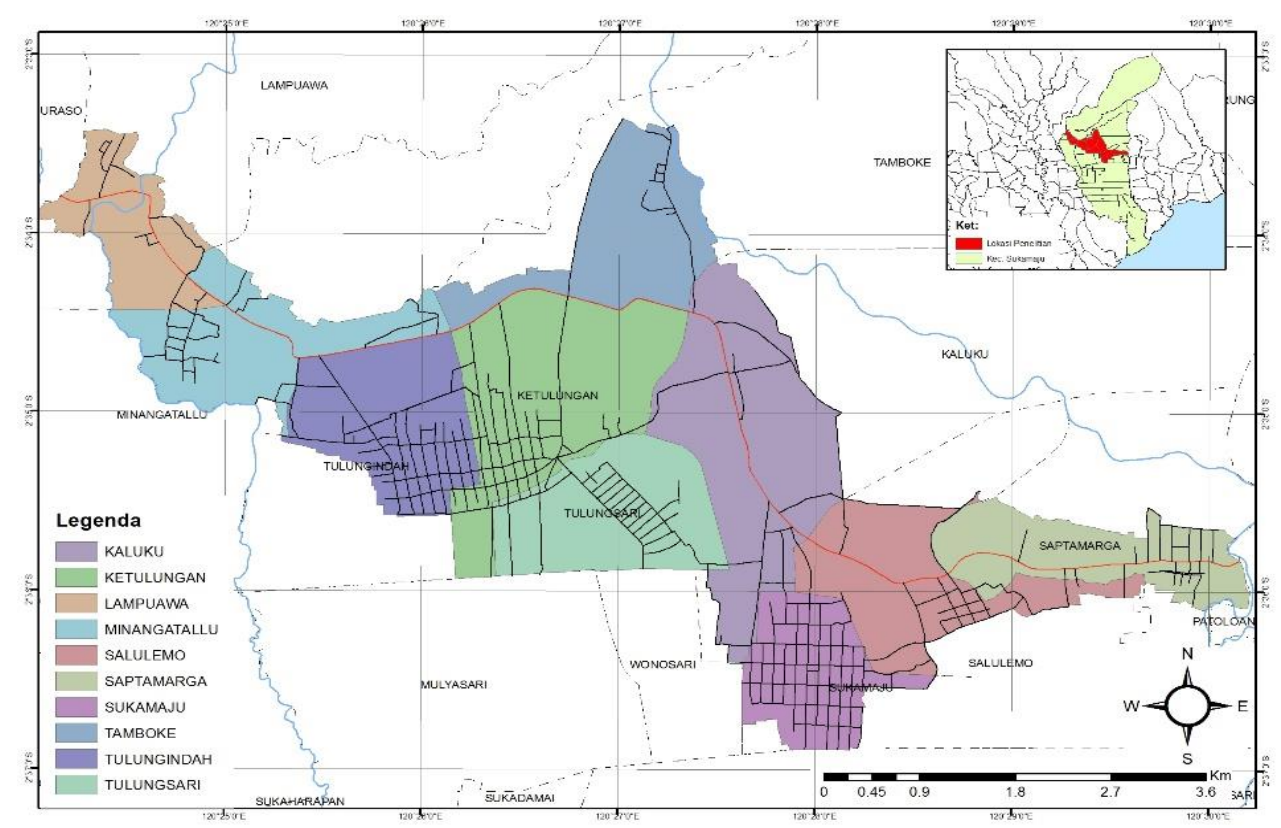

Gambar 1. Peta Lokasi Penelitian

layanan jasa ekosistem yakni penyediaan, pengaturan dan pendukung. Keterbatasan dan ketersediaan data maka penelitian ini hanya difokuskan pada layanan jasa penyediaan air dan pangan. Data yang dibutuhkan untuk penelitian ini meliputi data bentang lahan pulau dan data tipe vegetasi alami Kabupaten Luwu Utara dari Direktorat Jenderal Planologi Kehutanan dan Tata Lingkungan Kementerian Lingkungan Hidup dan Kehutanan 2018, data digitasi tutupan lahan bagian perkotaan sukamaju, Peta administrasi bagian perkotaan sukamaju dari RDTR Perkotaan Sukamaju Kabupaten Luwu Utara, Peta jaringan jalan bagian perkotaan sukamaju dari RDTR Perkotaan Sukamaju.

Tahapan dan pendekatan metode perhitungan dan penentuan daya dukung lingkungan indikatif berbasis jasa ekosistem terdiri dari klasifikasi karakterisitik ekoregion (bentang lahan dan Tipe Vegetasi alami) serta penutupan lahan, perhitungan dan pembuatan peta layanan/kinerja jasa ekosistem. Pendekatan jasa ekosistem merupakan konsep perencanaan, pengambilan keputusan dan pengelolaan yang komprehensif, yang menguraikan strategi pengelolaan terpadu tanah, air, dan sumber daya kehidupan yang meningkatkan konservasi dan pemakaian secara berkelanjutan dan berkeadilan. Pendekatan ekosistem dibangun diatas pemikiran bahwa seluruh ekosistem di dunia adalah terkait dan tidak satu ekosistem pun dapat berfungsi sebagai satu sistem yang seluruhnya tertutup.

Jasa ekosistem adalah manfaat yang diperoleh oleh manusia dari berbagai sumber daya dan proses alam yang secara bersama-sama diberikan oleh suatu ekosistem [7].

Jasa ekosistem adalah manfaat yang populasi manusia berasal, langsung atau tidak langsung, dari fungsi ekosistem. Jasa ekosistem juga merupakan aspek ekosistem yang digunakan (aktif atau pasif) untuk memberikan kesejahteraan manusia [8]. Selain itu, nilai indeks jasa lingkungan wilayah merupakan indeks terbobot dari masing-masing komponen jasa ekosistem. Secara teknis perhitungan dapat dilakukan pada tipe jasa ekosistem. Secara teknis dapat dilakukan pada tipe jasa ekosistem ataupun masing-masing komponen dalam jasa ekosistem [9]. Dalam kajiannya, MEA [7] mengemukakan bahwa relasi yang terhubung secara alami membuktikan adanya jasa ekosistem yang mutlak dikatakan bahwa jika terjadi suatu gangguan terhadap ekosistem, maka akan sangat memberikan pengaruh yang signifikan kurang baik bagi komponen-komponen yang ada didalamnya termasuk manusia. Hubungan yang terjalin antara jasa ekosistem dengan DDDTLH melibatkan suatu ekosistem untuk memberikan peluang bagi kesejahteraan manusia dalam pemanfaatan sumber daya alam.

Dalam daya dukung daya tampung berbasis jasa ekosistem, MEA mengklasifikasikan jasa ekosistem berdasarkan tipe manfaat kehidupan bagi manusia yaitu : 1) Jasa Penyedia (Provisioning) merupakan produk yang diperoleh dari layanan ekosistem seperti; Penyediaan pangan, Penyediaan air, Penyediaan bahan bakar dan material lain serta Penyediaan sumber daya genetik; 2) Jasa Pengatur 
(Regulating) manfaat yang diperoleh dari pengaturan proses layanan ekosistem; Pengaturan kualitas udara, Pengaturan iklim, Pencegahan dan Perlindungan terhadap bencana alam (banjir, longsor, kebakaran, dan tsunami), Pengaturan air, Pemurnian air dan pengolahan limbah, Pengaturan penyerbukan alami, Pengendalian Hama, 3) Jasa Budaya (Cultural) Manfaat non material yang diperoleh dari ekosistem; Budaya estetika: apresiasi pemandangan alam, Budaya rekreasi: peluang untuk kegiatan pariwisata dan rekreasi, Budaya warisan budaya dan Identitas: rasa tempat dan milik; 4) Jasa Pendukung (Supporting) Layanan yang diperlukan untuk produksi semua layanan ekosistem lainnya; Habitat dan Keanekaragaman hayati, Pembentukan dan regenerasi tanah, Produksi primer, dan Siklus hara.

Setiap kelompok jasa ekosistem saling mempengaruhi bagi dan menopang berbagai unsur kesejahteraan manusia dan ekonomi. Untuk setiap kelompok Jasa Penyediaan, Jasa Pengaturan, dan Jasa Budaya dipercaya memberikan efek langsung (direct effects) kepada tingkat kesejahteraan manusia, sedangkan untuk kelompok Jasa Pendukung memberikan dampak tidak langsung (indirect effects) terhadap kesejahteraan manusia. Keterkaitan tersebut dapat dilihat pada gambar 2.

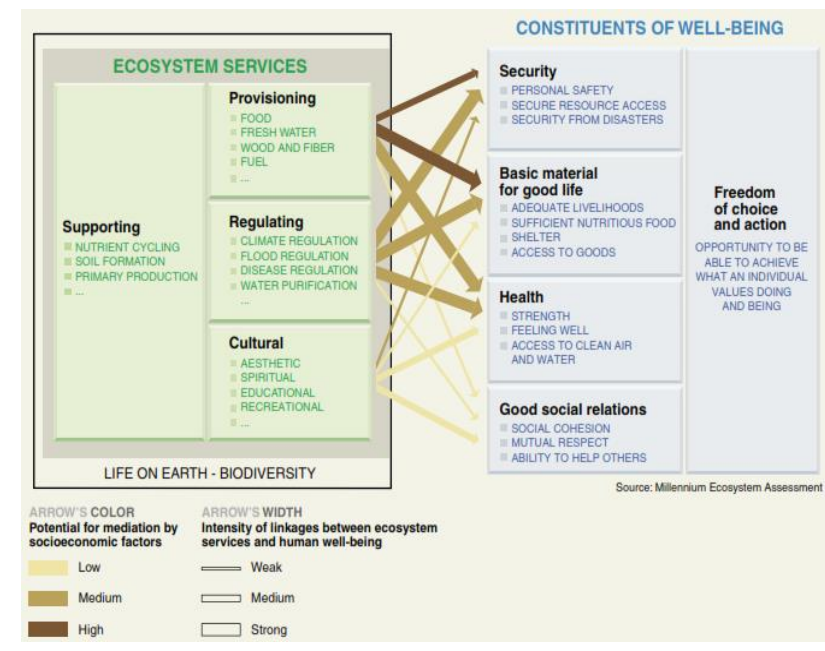

(Sumber : Millennium Ecosystem Assessment, Ecosystems and Human Well-being: Synthesis, 2005, 50)

Gambar 2. Ilustrasi Keterkaitan antara Ekosistem dan Kesejahteraan Manusia
Penelitian ini, menggunakan teknik analisis pembobotan dan skoring dimana perhitungan kinerja jasa ekosistem bagian perkotaan Sukamaju bersumber dari Direktorat Pencegahan Dampak Lingkungan Kebijakan Wilayah dan Sektor (PDLKWS), Direktorat Jenderal Planologi Kehutanan dan Tata Lingkungan Kementerian Lingkungan Hidup dan Kehutanan Tahun 2018 dengan kedalaman analisis spasial 1:250.000 yang telah ditetapkan untuk skorsing dan bobot Pulau Sulawesi. Skorsing dan bobot ditentukan dan diformulasikan oleh Direktorat Jenderal Planologi Kehutanan dan Tata Lingkungan Kementerian Lingkungan Hidup dan Kehutanan dengan menggunakan metode AHP (Analisis Hierarchy Process). Para pakar masing-masing menentukan bobot dan skor untuk bentang lahan, tipe vegetasi alami dan penutupan lahan kemudian membuat range 1-5. Dengan asumsi bahwa angka 1 (sangat rendah), 2 (rendah), 3 (sedang), 4 (tinggi), dan 5 (sangat tinggi) dapat dilihat pada "pers. (1)". Kuesioner yang telah diisi tersebut kemudian diolah menggunakan penjumlahan berbobot (Simple Additive Weighting) untuk menghasilkan nilai indeks jasa ekosistem yang dapat menggambarkan tingkat kelas daya dukung daya tampung lingkungan hidup berbasis jasa ekosistem.

Adapun perhitungan dan pembuatan kinerja jasa ekosistem, model matematik yang digunakan untuk mengetahui kinerja jasa ekosistem hidup tersebut adalah metode penjumlahan berbobot (Simple Additive Weighting), dengan penentuan bobot dan skor oleh pakar.

Kinerja Jasa Ekosistem; $f$ Bentanglahan, Vegetasi, Penutup Lahan $\}$ $f=($ wbl $x s b l)+($ wveg $x$ sveg $)+($ wpl $x s p l)(1)$

\section{Keterangan:}

$$
\begin{aligned}
& \text { wbl = bobot bentanglahan } \\
& \text { sbl }=\text { skor bentanglahan } \\
& \text { wveg }=\text { bobot vegetasi } \\
& \text { sveg }=\text { skor vegetasi } \\
& \text { wpl }=\text { bobot penutupan lahan } \\
& \text { spl }=\text { skor penutupan lahan }
\end{aligned}
$$

Cara mendapatkan informasi dan gambaran tentang kebutuhan dan ketersediaan air secara spasial dibutuhkan SIG [10]. Dalam hal ini kapasitas daya dukung lingkungan hidup terhadap jasa ekosistem tertentu direpresentasikan dalam bentuk indeks. Indeks jasa ekosistem dihitung dengan melibatkan nilai bobot jasa ekosistem terhadap bentuk lahan, tipe vegetasi dan 
penutupan/penggunaan lahan. masing-masing karakteristik tersebut akan dioverlay/ ditumpang susun menggunakan aplikasi Sistem Informasi Geografis (SIG) yakni dengan program ArcGis 10.4.1.

Hasil perhitungan indeks jasa ekosistem akan memiliki rentang nilai 1 (satu) sampai 5 (lima). Indeks dihitung untuk masing-masing jenis jasa ekosistem, adapun rentang kelas yang digunakan untuk setiap kinerja jasa ekosistem yaitu (a) Sangat tinggi $=4,21-5,00 ;$ (b). Tinggi $=3,41-4,20$ (c) Sedang $=2,61-3.40 ;$ (d) Rendah $=1,81-2,60$; (e) Sangat Rendah $=1,00-1,80$. Indeks yang telah dibagi menjadi 5 (lima) kelas kemudian nantinya akan disajikan dalam bentuk layout peta.

\section{HASIL DAN PEMBAHASAN}

\section{Ketersediaan Air}

Penentuan daya dukung khususnya dayadukung air suatu wilayah merupakan salah satu pendekatan dalam evaluasi pemanfaatan ruang wilayah [11]. Dalam lingkup ini ketersediaan air adalah pemenuhan kebutuhan untuk dimanfaatkan. Ekosistem memberikan manfaat penyediaan air bersih yaitu ketersediaan air bersih baik yang berasal dari air permukaan maupun air tanah (termasuk kapasitas penyimpanannya), bahkan air hujan yang dapat dipergunakan untuk kepentingan domestik, pertanian, industri maupun jasa. Penyediaan jasa air dipengaruhi oleh kondisi curah hujan dan lapisan tanah atau batuan yang dapat menyimpan air (akuifer) serta faktor yang dapat mempengaruhi sistem penyimpanan air tanah seperti penutupan lahan.

Menurut Sugandhy dan Hakim [12] dari hasil studi penelitian, industri, perhotelan, dan perkantoran, umumnya menggunakan sumber daya air tanah kedalaman lebih dari 40 meter. Dalam hal ini prediksi dimasa yang akan mendatang, jika tidak ditangani secara serius tentu kuantitas serta kualitas air tanah akan terganggu.

Pada lokasi penelitian, dapat dilihat dalam tabel 1, menjelaskan luas masing-masing kelas jasa ekosistem penyediaan air berdasarkan administrasi desa. Pada Tabel 1 dapat diamati bahwa luasan kelas jasa ekosistem air yang paling besar berada pada Desa Kaluku, namun pada klasifikasi indeks sangat tinggi hanya terdapat pada wilayah desa Lampuawa, Minanga Tallu, Saptamarga, dan Tulung Sari yang luasnya tidak begitu besar berkisar 0-2,4 Ha. Penyebarannya dapat dilihat pada Gambar 3. Secara keseluruhan jasa ekosistem penyediaan air terbagi menjadi lima kelas. Terdistribusi menjadi sangat rendah $46.90 \%$, rendah $45.41 \%$, sedang $7.12 \%$, tinggi $0.33 \%$, dan sangat tinggi $0.25 \%$. wilayah dominan pada kelas rendah (sangat rendah dan rendah) terdapat pada Desa Kaluku sebesar $15.85 \%$ atau dengan luas $356.28 \mathrm{Ha}$ dan Desa Katulungan sebesar $15.78 \%$ atau dengan luas 354.74 ha.

Tabel 1. Luas (ha) Masing-Masing Kelas Jasa

Ekosistem Air Menurut Administrasi Desa

\begin{tabular}{|ccccccc|}
\hline & \multicolumn{5}{c}{ Luas Kelas Jasa Ekosistem Air berdasarkan Adminstrasi Desa (Ha) } \\
\cline { 2 - 7 } Desa & Rendah & Sangat Rendah & $\begin{array}{c}\text { Sangat } \\
\text { Tinggi }\end{array}$ & Sedang & Tinggi & Grand Total \\
\hline Kaluku & 117,93 & 238,35 & - & 31,31 & 1,47 & 389,06 \\
\hline Katulungan & 25,83 & 328,91 & - & - & 0,39 & 355,13 \\
\hline Lampuawa & 143,08 & 1,21 & 2,36 & 10,60 & 0,49 & 157,75 \\
\hline Minanga Tallu & 105,353 & 41,88 & 1,75 & 75,44 & 0,34 & 224,76 \\
\hline Salulemo & 202,57 & - & - & 35,96 & 0,29 & 238,82 \\
\hline Saptamarga & 188,23 & - & 1,89 & 4,5 & - & 194,68 \\
\hline Sukamaju & 165,17 & - & - & 3,75 & - & 168,92 \\
\hline Tamboke & 3,62 & 219,44 & - & - & 3,52 & 226,59 \\
\hline Tulung Indah & 13,77 & 226,13 & - & - & 0,01 & 239,91 \\
\hline Tulung Sari & 140,31 & 86,02 & 0,03 & 11,64 & 1,42 & 239,42 \\
\hline Grand Total & $\mathbf{1 . 1 0 5 , 8 7}$ & $\mathbf{1 . 1 4 1 , 9 5}$ & $\mathbf{6 , 0 3}$ & $\mathbf{1 7 3 , 2 6}$ & $\mathbf{7 , 9 5}$ & $\mathbf{2 . 4 3 5 , 0 6}$ \\
\hline
\end{tabular}




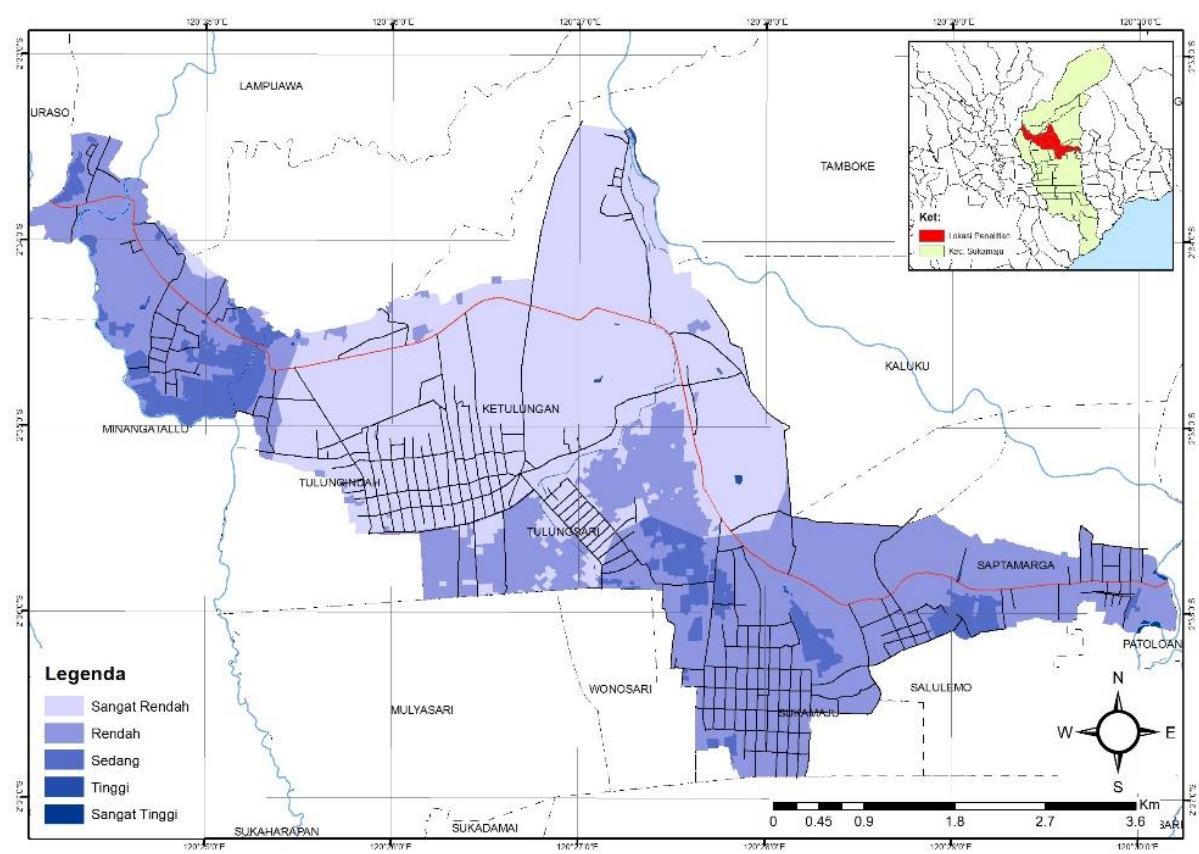

Gambar 3. Jasa Lingkungan Indikatif Penyediaan Air

\section{Ketersediaan Pangan}

Pangan yang dimaksudkan adalah ketersediaan tanaman (serealia dan non serealia) yang dapat dimakan dan ketersediaan hewan yang bisa dimakan. Ekosistem memberikan manfaat penyediaan bahan pangan yaitu segala sesuatu yang berasal dari sumber hayati (tanaman dan hewan) dan air (ikan), baik yang diolah maupun yang tidak diolah, yang diperuntukkan sebagai makanan atau minuman bagi konsumsi manusia.
Jenis-jenis pangan di Indonesia sangat bervariasi diantaranya seperti beras, jagung, ketela, gandum, sagu, segala macam buah, ikan, daging, telur dan sebagainya. Penyediaan pangan oleh ekosistem dapat berasal dari hasil pertanian dan perkebunan, hasil pangan peternakan, hasil laut dan termasuk pangan dari hutan. Luasan masing-masing kelas menurut lokasi kecamatan dapat dilihat pada Tabel 2.

Tabel 2. Luas (ha) Masing-Masing Kelas Jasa Ekosistem Pangan Menurut Administrasi Desa

\begin{tabular}{|c|c|c|c|c|c|c|}
\hline \multirow[t]{2}{*}{ Desa } & \multicolumn{6}{|c|}{ Luas Kelas Jasa Ekosistem Pangan berdasarkan Adminstrasi Desa (Ha) } \\
\hline & Rendah & $\begin{array}{l}\text { Sangat } \\
\text { Rendah }\end{array}$ & $\begin{array}{l}\text { Sangat } \\
\text { Tinggi }\end{array}$ & Sedang & Tinggi & Grand Total \\
\hline Kaluku & 11,54 & 45,90 & 31,27 & 196,68 & 103,67 & 389,06 \\
\hline Katulungan & - & 111,13 & - & 219,34 & 24,67 & 355,13 \\
\hline Lampuawa & 38,38 & 0,29 & 9,35 & 0,97 & 108,77 & 157,75 \\
\hline Minanga Tallu & 33,26 & 5,23 & 74,39 & 39,42 & 72,45 & 224,76 \\
\hline Salulemo & 34,17 & - & 35,11 & - & 169,53 & 238,82 \\
\hline Saptamarga & 53,99 & - & 4,85 & - & 135,83 & 194,68 \\
\hline Sukamaju & 99,99 & - & 3,75 & 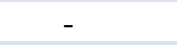 & 65,18 & 168,92 \\
\hline Tamboke & . & 36,19 & - & 189,99 & 0,40 & 226,59 \\
\hline Tulung Indah & 4,06 & 85,03 & - & 141,29 & 9,53 & 239,91 \\
\hline Tulung Sari & 9,80 & 32,71 & 11,67 & 55,11 & 130,13 & 239,42 \\
\hline Grand Total & 285,20 & 316,48 & 170,41 & 842,79 & 820,18 & $2.435,07$ \\
\hline
\end{tabular}


Sebagaimana dapat dilihat pada tabel 2, Desa Kaluku, Katulungan dan Tulungindah merupakan desa yang memiliki potensi pengembangan pangan, dengan melihat total luasan kelas jasa ekosistem pangannya, mulai dari yang terendah sampai dengan yang sangat tinggi maka pembangunan untuk tujuan lain harus dilakukan secara lebih berhati-hati. Dengan demikian, pemanfaatan lahan untuk usaha pertanian dan perkebunan tanpa diikuti dengan penerapan asas-asas konservasi tanah dan air, akan mengaibatkan menurunnya kualitas lahan [13] Dimana Intensifikasi lahan pertanian bisa dilakukan dengan cara penggunaan sistem tanam polikultur serta penggunaan bibit unggul [14] . Selain itu, ketersediaan pangan domestik, diperlukan usaha-usaha untuk mengurangi bahkan mencegah terjadinya konversi lahan-lahan pertanian yang produktif [15].

Sebaran klasifikasi ketersediaan pangan dapat dilihat pada Gambar 4. Jasa ekosistem penyediaan pangan terbagi menjadi lima kelas. Terdistribusi menjadi sangat rendah $13 \%$, rendah $11.71 \%$, sedang $34.61 \%$, tinggi $33.68 \%$ dan sangat tinggi $7 \%$. Jasa ekosistem penyediaan pangan yang tinggi dan sangat tinggi terkonsentrasi pada Desa Salulemo, Saptamarga, Tulung Sari dan Minanga Tallu. Bagian ini merupakan wilayah dengan dataran rendah (0-60 mdpl) yang sesuai untuk pengembangan tanaman pangan. Jika terjadi kegiatan pembangunan pada wilayah ini, kemungkinan nantinya akan dapat mengurangi ketersediaan pangan.

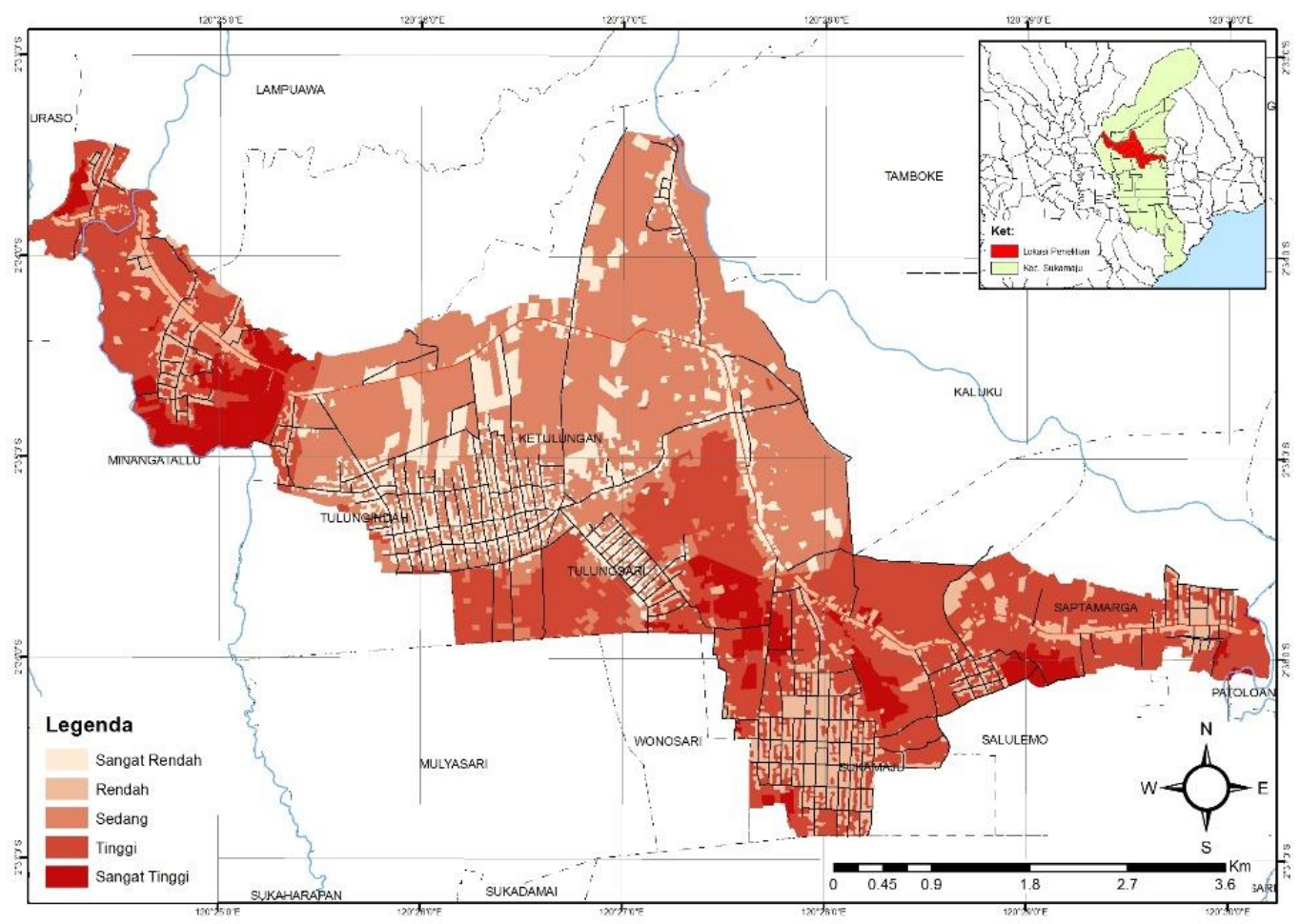

Gambar 4. Jasa Lingkungan Indikatif Penyediaan Pangan

\section{KESIMPULAN}

Hasil kesimpulan menunjukkan bahwa daya dukung lingkungan untuk penyediaan air tergolong kurang baik atau dalam status rendah. Faktor ini dipengaruhi oleh curah hujan, lapisan tanah atau batuan yang dapat menyimpan air serta aktifitas pemanfaatan lahan. Oleh sebab itu perlu upaya konkret untuk melindungi daerah-daerah yang merupakan basis dalam menyokong ketersediaan air. Sedangkan pada ketersediaan pangan status daya dukung masih tergolong relatif sedang. Namun, Kecamatan Sukamaju sebagai pusat pertumbuhan yang memiliki visi agropolitan tentunya harus mempertimbangkan pembangunan yang berfokus dalam bidang pertanian. Sehingga perlu upaya yang lebih optimal agar kondisi lingkungan sebagai penyokong ketersediaan pangan dapat lebih ditingkatkan. 


\section{DAFTAR PUSTAKA}

[1] Deputi Bidang Tata Lingkungan, \& Hidup, K L (2014) Pedoman Penentuan Daya Dukung Dan Daya Tampung. Jakarta: Kementerian Lingkungan Hidup Deputi 1 Bidang Tata Lingkungan Asisten Deputi Perencanaan Pemanfaatan SDA \& LH \& Kajian Kebijakan LH Wilayah \& Sektor.

[2] Paddiyatu N \& Pradoto W (2015) Pengaruh Karakteristik Sosial - Ekonomi Masyarakat Terhadap Pola Permukiman di Bantaran / Tepian Sungai Kahayan Kota Palangkaraya. Jurnal Pembangunan Wilayah \& Kota, 11(3), 340. https://doi.org/10.14710/pwk.v11i3.17584.

[3] Purwoko S (2018) Indikator Air Layak Minum dan Sanitasi Layak dalam Mendukung Upaya Kesehatan Lingkungan di Rumah Tinggal. Universitas Nahdalatul Ulama Surabaya Journal, 1(1), 62-67.

[4] Ndoen, Jeremias BB, \& Kinseng, RA (2018) Daya Dukung Lahan Kawasan Perkotaan Lewoleba Untuk Ketersediaan Pangan Dan Air Berkelanjutan. Jurnal Pengelolaan Sumberdaya Alam Dan Lingkungan (Journal of Natural Resources and Environmental Management), 8(3), 279-285. https://doi.org/10.29244/jpsl.8.3.279285

[5] Pemerintah Kabupaten Luwu Utara (2011) Peraturan Daerah Kabupaten Luwu Utara Nomor 2 Tahun 2011. Masamba.

[6] Admadhani DN, Hajil AHS, \& Susanawati LD (2014) Analysis of Water Supply and Water Demand for Carrying Capacity Assessment (Case Study of Malang). Jurnal Sumber Daya Alam Dan Lingkungan, 1(3), 1320.

[7] Millennium Ecosystem Assessment (2005) Ecosystems and Human Well-being: Synthesis. In Assessment of Climate Change in the Southwest United States: A Report Prepared for the National Climate Assessment. https://doi.org/10.5822/978-1-61091-484-0_1.

[8] Braat L, \& de Groot R (2012) The ecosystem services agenda : bridging the worlds of natural science and economics, conservation and development, and public and private policy. Ecosystem Services, 1(1), 4-15. https://doi.org/10.1016/j.ecoser.2012.07.011.

[9] Muta'ali, L (2015) Teknik Analisis Regional. Yogyakarta: Badan Penerbit Fakultas Geografi (BPFG), Universitas Gajah Mada.

[10] Sumberdaya J, Fadilah N, Tunggul A, Haji S, Widiatmono R, \& Sumberdaya J (2015) (Studi Kasus Kota Batu) Water Balance Model for Carrying Capacity Assessment (Case Study of Batu). Jurnal Sumberdaya Alam Dan Lingkungan, 1(2), 7-13.

[11] Santoso DH (2015) Kajian Daya Dukung Air di Pulau Bintan, Provinsi Kepulauan Riau. Jurnal Sains \& Teknologi Lingkungan, 7(1), 01-17. https://doi.org/10.20885/jstl.vol7.iss1.art1

[12] Aca Sugandhy RH (2009) Prinsip dasar kebijakan pembangunan berkelanjutan berwawasan lingkungan. Jakarta: PT. Bumi Aksara

[13] Manik, KES (2016) Pengelolaan Lingkungan Hidup. Jakarta: Prenadamedia Group.

[14] Rakhimatul Hidayah NH, \& Nugroho CP (2018) Dinamica Of Food Availability In Sidoarjo District. Journal of Chemical Information and Modeling, 2(3), 194-203. https://doi.org/10.1017/CBO9781107415324.004.

[15] Nugroho CP, \& Rini Mutisari (2015) Analisis Indikator Ketahanan Pangan Kota Probolinggo: Pendekatan Spasial. Agrise, Xv(3), 1412-1425.

(C) 2019 the Author(s), licensee Jurnal LINEARS. This is an open-access article distributed under the terms of the Creative Commons Attribution License

(http://creativecommons.org/licenses/by/4.0) 